\title{
LAKE TRANSPORTATION AND THE IRON-ORE INDUSTRY.
}

In examining the traffic statistics of the Great Lakes our attention is at once arrested by the enormous amount of iron ore that is annually transported. During the navigation season of 1895 , of the I $5,062,580$ net tons of freight sent through the St. Mary's Falls canal, 8,062,209 net tons were iron ore. At present approximately two-thirds of the iron ore consumed by the blast furnaces of this country is carried, during some portion of the journey from the mine to the furnace, over the waters of the Great Lakes. That this vast amount of ore from the Lake Superior region has affected the mining operations of the other ore-producing districts is a matter of general information. It may be of interest to point out the extent to which the exploitation of the mines in other portions of the United States has been affected by the output from the mines of the Lake Superior region.

Before developing the point just raised, it will be well, perhaps, to locate in a general way the regions in which large quantities of ore are now being mined. Iron ore is very widely distributed throughout the United States; with possibly three exceptions every state and territory in the Union has mined iron ore or contains deposits. But at present nearly the whole product is won from the mines of three districts.

The eastern region, and naturally the first to be noticed, covers a great extent of territory; but the mines of New York, New Jersey, Pennsylvania and Ohio have contributed nearly the whole of the output of this division. Within its borders all four of the varieties ${ }^{x}$ of ore are mined.

${ }^{x}$ For the sake of simplicity I shall use the classification of ores adopted by the United States Geological Survey, as follows: "(I) Red kematite comprises those ores in which the iron occurs as an anhydrous oxide, giving a red streak on a porcelain 
Pennsylvania is rich in all of the four different kinds of ore, but they seldom contain as high a percentage of iron as is now insisted upon by managers of blast furnaces. The bulk of Pennsylvania's product is now of the magnetite variety; this is largely taken from the Cornwall Ore Hills - three hills of iron ore situated in the eastern part of the state. This ore is suited to the manufacture of Bessemer steel, but is rather low in metallic iron, as it averages but 40 to 50 per cent. New York also produces the four different varieties of ore, but at present the bulk of the product is magnetite in character and is mined in the Lake Champlain district. Most of this ore is rich in metallic iron and some of it is of Bessemer quality. Very nearly the whole of the output of the mines of New Jersey is of the magnetite variety and much of it is of excellent quality. Many mines of this state are now practically exhausted and others are operated only at increasing cost because of the depth to which the ore has been removed and the narrowness of the veins. The ores of Ohio are carbonates and are comparatively poor.

The Lake Superior region, unlike the eastern region, embraces but a small extent of territory; it falls within the northern portions of the states of Wisconsin and Minnesota and the upper plate, the color of the ore being generally a brownish-red or red, although sometimes a dark gray, almost black. This class includes "red hematite," "fossil," or "Clinton" ores, "specular," "micaceous" ore, "slate" ore, etc., as well as some martite." (2) Brozen hematite, which contains more water than the red hematite, is generally of a brown or yellow color, and when powdered shows a brown or brownish-yellow streak on the porcelain plate. The varieties are known as "limonite," "turgite," "pipe" ore, "bog" ore, "goethite," "oolitic" ore, etc. (3) Magnetite comprises those ores in which iron occurs as a magnetic oxide, generally black or blue-black, or occasionally steel-gray or greenish in color, and which when powdered give a black streak on a test plate, and are attracted by a magnet. In this class is included some " martite" which is mined with magnetite. (4) Carbonate includes those iron ores which contain an excess of carbonic acid. They are generally gray, yellow, or rather buff and brown in color, and are tested by the use of hydrochloric acid. They comprise the "black band" ores, "clay ironstones," "spathic" ores, "siderites," etc.

From some mines, brown and red hematite, or red hematite and magnetite, or carbonate and brown hematite ores are obtained out of the same workings, the extent to which ores are hydrated or weathered transferring them from one class to another; or different classes of ore are found intermixed or alternating in the same deposit."John Birkinbine, The Production of Iron Ore in Various Parts of the World, p. I77. 
peninsula of Michigan. There are five great iron ore ranges within this district - Marquette, Gogebic, Menominee, Vermilion, and Mesabi. The Marquette range is located in Michigan; the Gogebic and Menominee are partly in Michigan and partly in Wisconsin, and the Vermilion and Mesabi lie wholly within the state of Minnesota. The ores of this region are red and brown hematites and magnetites; but the bulk of the ore now shipped is of the red hematite variety. Only the richer ores are now shipped, as most of the blast furnaces using Lake Superior ores are situated at great distances from the mines.

The third great ore region is located in the South, and embraces the central portion of Tennessee, the northern part of Alabama, and northwestern Georgia; it is generally known as the Alabama-Tennessee region. This division ranks next in importance to the Lake Superior district as a contributor to the iron ore output of the United States. Nearly all the ore now mined in this region is red and brown hematite; it is neither so rich in metallic iron nor so free from deleterious ingredients as are the Lake Superior ores.

It was stated at the beginning that the very large movement of ore from the Lake Superior region has affected mining operations in the other districts. In order to show the amount of ore contributed by the various regions to the total for the United States in a form easily comprehensible, and also in order more clearly to present the comparative development of the different districts, the figures covering the production of iron ore in the several regions, and in the United States as a whole have been put into the form of a chart. As reliable and complete data are not obtainable, it has not been attempted to make the chart cover the years previous to I880. ${ }^{\mathbf{1}}$ As the changes which it is desired to point out have for the most part taken place since I880, the absence of statistics for the earlier years is a matter of but little concern. But the meagerness of information concerning the

${ }^{x}$ For the census year 1870 , the facts are given in the appendix, and it is also there explained in what respect the figures of that census are faulty. The items which were combined to form totals that appear in the chart are given in greater detail in the same place. 
production of iron ore during the decade beginning with the year I 880 is cause for regret, for it was during this period that the greatest changes occurred in the relative importance of the ore regions. It will be noted that during the first ten years there is perfect uniformity of movement in the lines which represent the total production for the United States, and those for the eastern and southern divisions. These lines do not accurately reflect actual conditions - the statistics that show the production during the years intervening between I 880 and I 889 are not obtainable. Such facts as can be obtained are given in the appendix.

That the importance of the Lake Superior region cannot easily be overestimated is made clear by the chart; from a comparatively unimportant position it has, in the course of a decade and a half, come to contribute almost twice as much ore as all the other parts of the United States combined. In the census year I 880 the total production for the United States was 7, I 20,362 long tons; to this amount the lake region contributed but I,677,8 I 4 tons, or 23.6 per cent. of the total output. During the year I 895 , I $5,957,614$ long tons of ore were mined in the United States, and of this amount $10,328,248$ tons or 64.7 per cent. were taken from the mines of the lake region. The bare figures without further explanations do not, however, fully reflect the importance of the northern district, for Lake Superior ores are very much richer in iron than the ores of the other regions. If the quality as well as the quantity of the ore be taken into consideration the lake region is entitled to even a more important position than would be assigned to it on a simple tonnage basis of comparison.

In striking contrast with the increased production of the lake region is the rapid decrease in the amount contributed by the great mining states of the eastern region. During the census year I 880 the mines of New York, Pennsylvania, New Jersey, and Ohio yielded 4,243,372 long tons of ore, the total product of the United States being but 7,120,362 tons. The production of these states fell off slowly in the years following I880, but after 1889 the decrease was rapid and continuous until 1895 


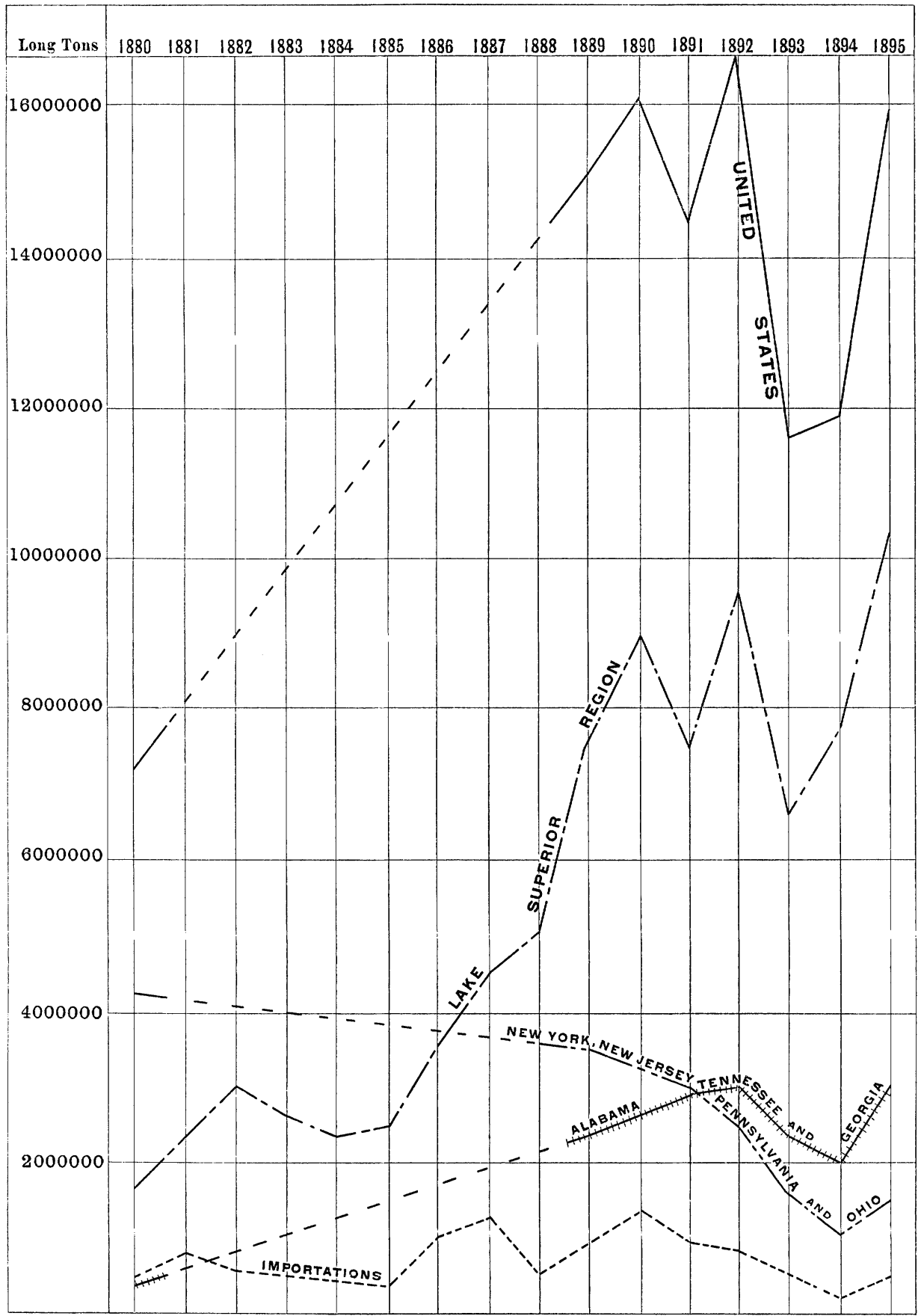

This content downloaded from 128.143.023.241 on August 09, 2016 23:19:31 PM All use subject to University of Chicago Press Terms and Conditions (http://www.journals.uchicago.edu/t-and- 
when there was a break in the downward movement. The share of these four states in the total output of $15,957,6$ I 4 long tons for 1895 was $1,534,863$. Expressed in percentages, there was raised from the mines of these states during the census year $1880,59.59$ per cent. of the total product of the mines of the United States, and in 1895 but 9.62 per cent.-an enormous falling off. This very great contraction ${ }^{\mathbf{x}}$ of the product of New York, Pennsylvania, New Jersey, and Ohio is the more surprising because most of the blast furnaces of the United States are located within their boundaries.

The output of the southern district has largely increased during the period covered by the chart, but the progress of this region has been much slower than that of the lake division. The southern district is in a very large measure isolated; its ores are not thrown into direct competition with the lake ores, as is the case with the eastern ores, for transportation charges act as a barrier and prevent such competition. The extent of the substitution of lake ores for eastern ores is shown by the chart (p. 26). It yet remains to be shown why the former ores are preferred to the latter, and how it is possible to carry ores from the mines of Minnesota to the furnaces of Pennsylvania and sell them at such a price that they will be taken in preference to native ores. Lake Superior ores are now transported almost to the Atlantic seaboard ${ }^{2}$ and there sold in competition with both native and foreign ores. ${ }^{3}$ That lake ores have quali-

x The ores of the eastern region must also meet the competition of foreign ores. There has been, however, no large increase in importations, hence the decreased output of the eastern region cannot in any appreciable measure be ascribed to foreign competition. During the past few years there has been a decrease of importations. It is therefore very clear that the excessive competition of imported ores does not explain the limited output of the eastern mines. Beginning with the year 1872 the importations will be found in table II of the appendix; they are also represented by the lowest line of the chart for the years which it covers.

${ }^{2}$ The blast furnaces in New Jersey and eastern Pennsylvania receive a portion of their supply of ore from the Lake Superior region.-See Eleventh Census: Mineral Industries, p. 26 ; and The Production of Iron Ores in Various Parts of the World, p. 188.

3 The ability of foreign ores to compete is of course affected by the import duties paid. Previous to August 28, I894, the duty was 75 cents per ton; under the tariff act of 1894 it is 40 cents. 
ties which commend them to iron masters is obvious. The high esteem in which they are held is due partly to their great richness in metallic iron, partly to their freedom from deleterious ingredients, and to some extent to their excellent physical condition. All of these factors enter in, in determining the value of an iron ore. In general a rich ore requires less fuel to smelt it ; it also has less foreign matter to be fluxed out and thus a smaller amount of limestone will suffice for fluxing. If a rich ore be used there is therefore a threefold saving: (I) because an ore rich in metallic iron generally reduces more readily than a lean ore; (2) as less limestone is necessary, a smaller amount of fuel will be needed to smelt the flux, and (3) there is a saving of fluxing material which, in the case of a large establishment, amounts to a considerable sum in the course of a year. With rich ores, as less flux and fuel are required, the labor cost of handling the raw materials is smaller and as less cinder is made, the expense of providing space for this cinder and means for handling it is consequently reduced. The richer ores together with the proper quantities of fuel and flux, occupy less space in the blast furnace than the leaner ores combined with the fuel and flux required to reduce them, and therefore generally permit of more rapid "driving." In the case of the richer ores there is, therefore, a smaller cost per ton of product, for interest on the plant, management, and other fixed charges, because these expenses are distributed upon a greater tonnage than would be the case if lean ores were used.

Other things being equal the smaller the amount of phosphorus, sulphur, and titanic acid and other undesirable substances $^{x}$ which the ore contains the greater will be its value. If

I "As won from the earth iron ores carry in greater or less proportions other elements, such as phosphorus, sulphur, manganese, titanium, chromium, copper, etc., which affect their value for specific uses, as do also the amounts of silica, lime, alumina, magnesia, etc.; these latter, however, generally influence the percentage of metal obtainable from the ore, while the first named, as a rule, are more likely to affect its quality."-John Birkinbine, The Manufacture of Pig Iron in Pennsylvania, p. 2.

It should not be understood that these substances are always injurious, for such is not the case. For instance, if the iron produced is to be used for foundry purposes 
an ore contains more than one part phosphorus ${ }^{\mathbf{x}}$ to every one thousand parts metallic iron it is unfit for the manufacture of steel by what is now the cheapest method - the acid Bessemer process. This is a very damaging disqualification, for at present the owners of the Bessemer steel works are the largest purchasers $^{2}$ of iron ore and pay the highest prices. Yet another important condition is to be added; not only must the amount of phosphorus in the ore be small but it must also be uniformly distributed, otherwise, in case the Bessemer converter be used, the steel manufactured from the ore will vary in quality with every discharge of the blast furnace. ${ }^{3}$

This is the case because practically all of the phosphorus in the ore goes into the pig iron, and is not removed from it by the ordinary Bessemer converter. To make the matter perfectly clear, an illustration may be given. Suppose that the quantity

silica is not harmful if great strength is not desired; in fact quite the contrary is true, for the silica gives the iron greater fluidity, thus making it a better casting iron.

'There is now a tendency to insist on a still lower percentage of phosphorus; late specifications for steel rails do not accept 0. I phosphorus, but demand 0.085 phosphorus.

${ }^{2}$ The extent and growing importance of the demand for Bessemer ores is indicated by the following percentages, which give the proportion of Bessemer pig iron to the total pig iron product of the United States :

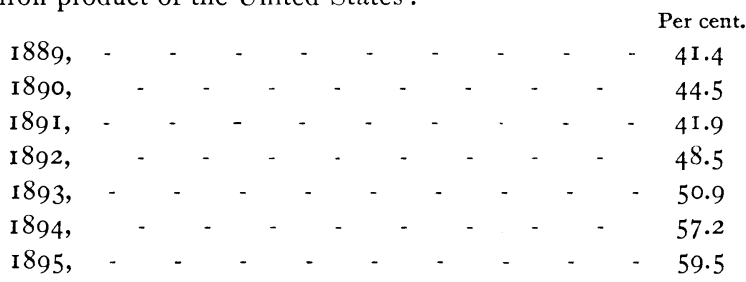

"As some iron ores not within the Bessemer limit of phosphorus were used in admixture with low phosphorus ores in the production of Bessemer pig iron, and as many of the ores used for producing foundry and mill irons carry lower percentages of metal than those smelted in the production of Bessemer pig iron, the proportion of Bessemer ore will not be as great as that shown for the pig metal, but the percentages are sufficiently close to indicate the growing increase in the employment of such material." -John Birkinbine, Production of Iron Ores in 189.5 , p. 8.

3 For the information of those who are unacquainted with the manufacture of steel it may be stated that the iron ore is reduced to metal in the blast furnace, and then placed in the Bessemer converter and changed to steel. 
of phosphorus in the ore as it comes from the mine shows rather large variations but that the average of phosphorus falls below the Bessemer limit. Also suppose that the charges of the furnace to which the ore is brought vary in the amount of the phosphorus they contain - some being very low and others very high in phosphorus content. Such being the case, the steel produced from the iron resulting from the charges very low in phosphorus will contain but little of this element. The steel from the charges high in phosphorus will contain a very large amount, and it will therefore be unfit for the higher uses to which steel is put. This difficulty can in a measure be obviated by frequently testing the ore and then mixing it in proper proportions, but this involves great expense.

As was stated above, the lake ores find favor with iron masters because they possess in a very high degree the three essential qualities of a good iron ore. That a definite conception of the relative standing of the ores of the various districts may be formed, the results of the best analyses we have will be submitted. The results of the very numerous analyses made by Professor Raphael Pumpelly of the ores mined in the census year I880, will first be given. In some localities the character of the ore mined has changed considerably since his examinations were made; for these localities the necessary corrections will be made, so as to show existing conditions. The following is a portion of Professor Pumpelly's table showing the average per cent. of metallic iron in the ore mined during the census year $1880:{ }^{1}$

Eastern region.

Average per cent. of

New York metallic iron in ore

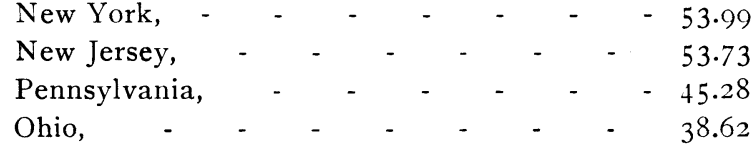

Southern region.

Alabama, - $\quad$ - $\quad$ - $\quad$ - $\quad$ - $\quad$ - 50.67

'Tenth Census: Mining Industries, p. I9. The census year began June I, I879, and ended May 31, I880. 


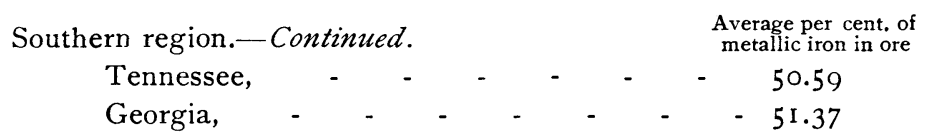

Lake Superior region.

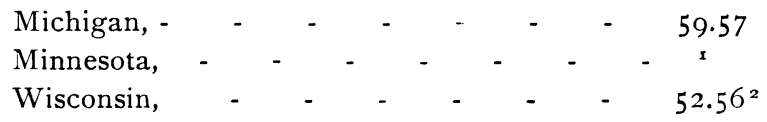

There has been no great change in the iron contents of the ores mined in the eastern region, yet some of the best deposits have been exhausted. Hence, if a test were now made, the ores of this district would not appear in so favorable a light as they did in 1880 . It is being found necessary to an increasing extent to improve ores by washing, jigging, ${ }^{3}$ and by the use of magnetic separators.

There has been even a greater change since 1880 in the quality of the southern ores. The average yield of the ores used by the blast furnaces of Alabama during the last census year was 44.4 per cent. ${ }^{4}$ The Clinton fossil ores (red hematite), which now constitute the bulk of the ore mined in this district, yield on an average from 42 to 47 per cent. of metallic iron. The southern brown hematites are not so good as the Clinton ores; if properly washed, however, they yield from 45 to 50 per cent. of iron. ${ }^{5}$

The lake ores are somewhat better in quality than those mined in 1880. In the opinion of David T. Day, special agent on the mineral resources of the United States for the eleventh census, the ores which were shipped to distant furnaces contained on the average 60 per cent. of metallic iron. The ores which were consumed in furnaces near at hand averaged 58 per cent. of iron; but as these were relatively unimportant the aver-

${ }^{1}$ Minnesota did not become a producer of iron ore until the year 1884 .

${ }^{2}$ Wisconsin's mining operations were wholly carried on in a different part of the state from where they now are, so that the figures for this state are quite meaningless.

3 In jigging, the crushed ore is agitated in a jigger, water being introduced for the removal from the ore of sand, clay, and earthy matter.

${ }^{4}$ Eleventh Census: Mineral Industries, p. I1.

5 The Productions of Iron Ores in Various Parts of the World, p. 23. 
age of 60 per cent. was not much reduced. Since Mr. Day made his report the output of the Vermilion range has been appreciably increased, and the Mesabi has suddenly sprung into prominence as a producer of iron ore. The latter now holds second place among the ranges. As the ores which are shipped from these ranges are richer in iron than those of the older ranges, the census figures are now, perhaps, a trifle too low. Mr. Franklin H. Head, an authority on the ores of the lake district, supports me on this point. In a recent letter, he says : "I think a fair average of the ore shipped would yield in the furnace sixtytwo tons of iron to each roo tons of ore."

Unfortunately it is impossible to give equally exact information concerning the impurities in the ores of the several districts as has been given of the iron contents. Perhaps less than onefourth of the ore of the eastern district can be classed as Bessemer; much of it contains large amounts of sulphur, and some of it carries a small amount of copper, and some of it has considerable quantities of titanium. The ore of the great Cornwall deposits contains on the average about 2.5 per cent. of sulphur and requires preliminary roasting in kilns to drive off a portion of this and an excess of lime in the blast furnace to eliminate the balance. About one-half of the sulphur is removed by the roasting, which costs about twenty cents per ton for fuel and handling. This ore also contains a small amount of copper, but still large enough to be troublesome in some subsequent metallurgical processes. Many of the ores of New York contain titanium. In reducing these ores, greater care must be exercised in fluxing; the furnace must also be run under special conditions of temperature and pressure of blast, otherwise titanium deposits will form in the furnace. This special condition of lower heat, considered more fayorable to smelting of these ores, requires more fuel. These disadvantages have prejudiced furnace managers against ores containing titanium.

In many cases the physical condition of the eastern ores is against them. The magnetites of New York and New Jersey are very refractory; they are not easily penetrated by the reducing 
gases of the furnace because of their exceedingly great density. Furnace managers assert that they require more fuel and care to smelt them, and, therefore, other things being equal, they prefer the softer hematites of the lake region. It is no longer found profitable to mine carbonate ores, for they must be roasted to drive off carbonic acid before they can be charged into the furnace. The cost of mining is also excessive as they generally occur in thin seams, or in scattered deposits.

The southern ores are non-Bessemer in quality; they are either too high in phosphorus, or else this element is very unequally distributed. A noteworthy exception to this statement is the Cranberry ore of western North Carolina. Other ores of the same general characteristics are thought to exist in the same part of the state and in Roan Mountain of eastern Tennessee, and possibly in the northwestern part of South Carolina. With these exceptions no extensive deposits of low-phosphorus ores are known to exist in any southern state. The southern ores generally contain considerable quantities of sulphur and the percentage of silica and lime varies greatly.

Most of the ores of the lake region are low in phosphorus, and the larger portion of them is of Bessemer quality. The percentage of Bessemer ores for the whole lake region is depressed by the contributions of the Menominee range, which produces mainly non-Bessemer ores. The lake ores are very free from sulphur, and generally contain no titanic acid. Furnace managers have experienced some difficulty with Mesabi ores because of their finely comminuted state ; but this trouble may be considered as temporary in character for the blast furnace managers may be relied upon to modify their furnaces and methods in such a manner as will enable them to use this large and valuable deposit.

It has been seen to what extent the lake ores have supplanted the eastern ores. I have now shown why the lake ores are preferred by the iron masters of the East to the ores mined nearer to their furnaces. Among the reasons for this preference are also found the facts which make it desirable to move the ore. There then remains to explain the peculiar combination of 
conditions which renders it possible to mine and transport these ores almost half way across the continent and yet sell them at such prices that they are taken in preference to the native ores.

It is obvious that in order to be available the ore must be found in favorable condition; it usually occurs in large deposits rather than in narrow veins of varying depth. As a result it can be more cheaply mined, for labor-saving machinery can be used, and there is also much less waste material to be handled. The great extent of the deposits permits large production and its incidental economies. The steam shovel is an example in point; it is employed to dig and load ore from open cuts $^{x}$ and to load ore on cars from stock piles. During one day in the summer of I896 three steam shovels, working fourteen hours each, dug and raised from the natural bed of the Oliver mine of the Mesabi range, IO,700 gross tons or 428 cars of ore. Twenty-five-ton ore-cars have been continuously loaded from the ore bed at the rate of two and one-half minutes per car; the largest shovel ${ }^{2}$ has occasionally been able to load as much as 5000 tons or 200 cars in a day of ten hours. It is estimated that the average cost of loading the ore into cars from the bed of this mine is less than five cents per ton. Before the shovels could be put to work on the ore it was necessary to remove a considerable amount of drift; but this expense, if averaged on all the ore which can be secured from the mine, would not exceed five cents per ton, and in all probability would be much less. The cost of stripping and of raising the ore practically represents the cost of mining this deposit, and these items combined aggregate less than ten cents per gross ton. ${ }^{3}$

The transportation facilities have been a most important feature in enabling the ore of the Lake Superior region to com-

I Mines are either open cut or underground; the ore in the mines of the former class is usually near the surface and is obtained by stripping off the overlying glacial drift.

${ }^{2}$ This shovel is mounted on extra heavy railroad car trucks of standard gauge; it weighs 90 tons, has engines of 190 horse power and is equipped with a dipper having a capacity of $2 \frac{1}{4}$ cubic yards, or five tons of ore.

3 Iron Age, vol. lviii. No. I6, p. 725. 
pete at distant points. Several ore roads ${ }^{\mathbf{I}}$ equipped with cars designed for the ore traffic have been constructed, ${ }^{2}$ and expensive terminals have been built. At the shipping ports these consist of docks built as high as fifty-seven and two-thirds feet above the water and so constructed that the ore trains can be run out upon them. ${ }^{3}$ The docks are equipped with pockets having a capacity of from 65 to 180 tons, into which the ore is unloaded from the cars by means of drop-bottoms. From the pockets of the dock the ore falls through iron chutes into the holds of the vessels which are run up alongside of the dock. By these appliances, handling of the ore is avoided from the time the ore leaves the mine until it reaches the receiving port where it is shoveled into buckets lowered into the ship's hold. Very little manual labor is required in these operations; sometimes it is necessary to start the ore by poking it with poles but generally its own weight is sufficient to move it.

The ore-receiving docks at the lower lake ports are equally well fitted for the work they perform. They are equipped with machinery well adapted to the rapid removal of the ore from the holds of the vessels at a very small cost. The outlay for shoveling the ore into buckets which are lowered into the holds

${ }^{x}$ The iron ore mines of each of the five ranges constituting the lake region are situated at some distance from the lakes. The nearest mines of the Marquette range are 12 miles from a shipping port; none of the mines of the Menominee range are less than $4 \mathrm{I}$ miles from a shipping port. The Gogebic range is about Io miles from the lake, but the nearest shipping point is 39 miles distant. The mines of the Minnesota ranges are still further removed from the lake; the Tower mines of the Vermilion range being 69 miles from a shipping point, and those at Ely 26 miles further removed. Of all the ranges the Mesabi has the farthest to ship its ores, some of the ores of this range being shipped I Io miles; Two Harbors and Duluth, Minn., and Superior, Wis., are the shipping ports of this range.

2 For the transportation of the ores of Minnesota, over 400 miles of standard gauge railroad have been constructed through what was a trackless wilderness ten years ago.

3 There are now on Lakes Michigan and Superior twenty-three of these docks (including those in process of construction), having a total of 4624 pockets, with a combined capacity of 633,804 gross tons, erected at a cost of $\$ 6,849,529$. They are located as follows: Five at Two Harbors, two at Duluth, one at Superior, three at Ashland, four at Marquette, one at St. Ignace, one at L'Ause (now abandoned), five. at Escanaba, and one at Gladstone. 
of vessels is the chief item; it varies from Io to I 5 cents per long ton, being done by manual labor. With the improved equipment of some of the docks the ore in buckets is raised from the hold, carried back 350 feet on the dock and dumped, at a total cost (including labor, depreciation of plant, interest, and fuel) of from I to $I .5$ cents per ton. Much of the ore, instead of being dumped on the stock pile, is loaded on cars and carried by railroad to furnaces located from 60 to 475 miles from Lake Erie ports.

Thus farattention has been directed merely to the labor which is economized by the improved docks which have been constructed. But these docks are also partially responsible for the very low transportation charges which prevail. Instead of losing days in loading and unloading, as was once the case, but a few hours are now lost. This statement is scarcely strong enough, for if averages could be obtained it might be found that it does not now require so many hours to take and discharge cargoes as it did days not long ago. Vessels lose almost no time at all at the docks ; it is almost literally true that they are constantly going or coming. With the finely comminuted ores of the Mesabi range, which run rapidly from the pockets down the chutes, vessels can be loaded in seventy minutes with 2500 tons of ore. ${ }^{x}$ There is also great expedition in the unloading of vessels. With the appliances possessed by the best docks the largest vessels can be unloaded in I 2 to I 4 hours. ${ }^{2}$ It is perhaps unnecessary to direct

x The dispatch with which vessels are now loaded will perhaps be better appreciated if comparison is made with the crude methods which once prevailed. In the early days on the Marquette range, the ore was conveyed from the mines in wagons and dumped on a dock. From the dock the ore was transferred to the ship by the ship's crew. After a time a tram road was built on which the cars were drawn by mules out upon the dock, where the ore was dumped upon an apron from which it could easily be loaded onto the ship. In this apron we have the rudimentary pocket. It was not long after the construction of this road that the pockets, which are now such an important adjunct of the docks, made their appearance in an experimental way. With the construction of the railroad from the mines of the Marquette range to the shipping port of the same name, the system of handling the ore which now obtains was rapidly perfected.

${ }^{2}$ This represents a vast improvement over the primitive methods which were in vogue until twelve or thirteen years ago. Formerly the ore was lifted from the hold in 
attention to the fact that a vessel's daily expenses are almost as large while in port as during passage, and therefore that dispatch in loading and unloading means a large saving. Of course there is practically no expense for fuel while the vessel is in port, but this is the only item of importance which is materially reduced. And it is not of so great importance as is usually imagined; this item, e. g., being only 28 per cent. of the total cost of running the ships of the Peninsular and Oriental Steamship Company. ${ }^{x}$

Not only has the volume of the business in iron ores warranted the expenditure of large sums on terminal facilities, but, also the expenditure of even much larger amounts on the instruments of transportation. Vessels of great size and of special design have been constructed for this trade. For the most part lake vessels have open holds - the whole cargo of coarse freight being carried in a single compartment. This permits economical handling and trimming of cargo. The strength usually obtained by transverse bulkheads is, in the main, secured by deckbeams, extra shell plating, stanchions, and intercostals. Several of the iron-ore companies have built fleets adapted to the requirements of the ore business. The Bessemer Steamship Company has a fleet of nine large steamers and seven barges, all of recent design and construction. These vessels have an aggregate net registered tonnage of 42,699 tons, and a total gross registered tonnage of 47,805 tons, and have an actual carrying capacity of 70,000 gross tons on a mean draft of 16 feet. $^{2}$ The Minnesota Iron Company has a fleet capable of carrying 32,000 gross tons per trip. It was estimated that the floating equipment on the Great Lakes January I, I 896 , employed primarily in the transportation of ore, had a value of $\$ 46,680,207 . .^{3}$

The ores of the Lake Superior region have qualities which buckets by horse power, dumped into wheelbarrows, wheeled back on the dock and emptied on the stock pile.

I Report of Commissioner of Navigation, I894, p. 25.

$=$ These facts were kindly furnished by Mr. L. M. Bowers, General Manager of the Bessemer Steamship Company.

${ }^{3}$ Blue Book of American Shipping (1896) p. 205, published by the Marine Review, Cleveland, Ohio. 
render them very valuable to the iron masters of the iron and steel producing districts of the eastern states and therefore it becomes desirable to move them. It is the perfection of the transportation facilities that renders this possible. Effective terminal facilities together with efficient instruments of carriage, have made possible the very low freight rates that have prevailed and without which the ore could not be moved. During the navigation season of 1895 , large quantities of ore were carried from the head of Lake Superior to the lower lake ports, a distance of $889^{1}$ statute miles, for eighty cents per gross ton ${ }^{2}$ which is equivalent to a ton-mile charge of but $\frac{9}{10}$ of a mill. This rate, although very low, was much reduced during the summer of $\mathrm{I} 896$, the rate being but sixty cents for some weeks. This rate is equal to but $\frac{67}{100}$ of a mill. When it is remembered that a ton-mile charge of three mills on railroads ${ }^{3}$ is regarded as something exceptional, it will be realized how very low the lake rates on iron ore are. Mr. Carnegie states that the directors of the new mineral road between Lake Erie and Pittsburgh hope to reduce the cost of hauling iron ore and coal to a little below three mills per ton per mile, ${ }^{4}$ but this rate has yet to be made. If lake rates were as high as rail rates the ore of Minnesota could not be moved. When it is known that the price of red hematites of Bessemer quality in Cleveland during the early spring of 1895 was but $\$ 2.80,5$ and that the price of this ore varied from $\$ 4.00$ to $\$ 4.25^{6}$ in the summer and autumn of 1896 , it will at once be understood how absolutely important it is that

' This is the distance as given in Eleventh Census: Transportation Business, Part $I I$, p. 29I, from Duluth to Ashtabula, the chief receiving port of Lake Erie.

${ }^{2}$ Blue Book of American Shipping (1896), p. 229. The contract rate made at the beginning of the season, which covered the greater part of the ore shipped.

3 This rate has been made by railroads on anthracite coal shipped to distant western points; it has also been made on other long distance traffic in a few cases. Iron Age, vol. lviii. No. 14, p. 622.

4 1bid., vol. lviii. No. 14, p. 622.

5 Ibid., vol. lvii. No. 2, p. 155.

${ }^{6}$ Ibid., vol. lvii. No. 22, p. 1263 and vol. Iviii. No. I3, p. 595. In I894 Bessemer standard ores sold for $\$ 2.65$ per ton and non-Bessemer for $\$ 2.00$ per ton at lower lake ports. Ibid., vol. lvii. No. I, p. 24 . 
freight rates should be low. If the ton-mile rate were three mills, which is regarded as quite exceptionally low on the railroads, the freight charge for transporting ore from Duluth to Cleveland would be $\$ 2.54$ - a rate higher than the traffic could bear.

In view of the facts which have been presented, it ought not to be difficult to understand why the ores of the Lake Superior region are supplanting the ores of the eastern region. This substitution has been going on rapidly, and should the demand for steel continue to increase at the expense of that for iron, this substitution $^{x}$ will persist unless methods be discovered by which good steel can be made cheaply from ores that cannot now be used to advantage.

University of Chicago.

George G. Tunell.

' There is apparently no likelihood that the ores of this region will be speedily exhausted, for we have the testimony of an expert that a single range will yield double the amount that the whole lake region has thus far produced. Mr. John Birkinbine says of the Mesabi: "No other iron range thus far discovered possesses greater apparent reserves; conservative estimates formulated from the records of properties now exploited and worked, together with others determined by systematic explorations and analyses, show that the Mesabi range can supply ore (which will equal in average iron and phosphorus contents) double the quantity [or 200 million gross tons] which the entire Lake Superior region has produced in fifty years. In this estimate there are not included a number of properties which have been imperfectly explored." - The Production of Iron Ores in 1895, p. 16. 